\title{
RETROCAVAL URETER: A CASE REPORT
}

Deepak Pankaj ${ }^{1}$, Sanjay Prakash², Tushar Singh ${ }^{3}$

\section{HOW TO CITE THIS ARTICLE:}

Deepak Pankaj, Sanjay Prakash, Tushar Singh. "Retrocaval Ureter: A Case Report". Journal of Evolution of Medical and Dental Sciences 2015; Vol. 4, Issue 15, February 19; Page: 2613-2616,

DOI: $10.14260 /$ jemds/2015/375

ABSTRACT: A Retrocaval Ureter (Circumcaval Ureter) is a developmental anamoly of inferior vena cava (IVC). Unfortunately both term suggest that ureter is at fault whereas in reality it is the IVC. There are two types of retrocavalureter.ie. The high loop and low loop. This abnormality occurs as a result of the right supracardinal system failing to develop normally. The right posterior Cardinal vein persists and therefore ends up passing in front of ureter. With one exception, the anamoly always occurs on right side as this is the site of normal IVC. Many patients are asymptomatic but depending on the degree of compression, patients may develop partial ureteral obstruction or recurrent urinary tract infection (UTI) due to urinary stasis. Though congenital anamoly, patients do not present until 3 rd to 4 th decade of life resulting from hydronephrosis (HDN). Surgical correction of the ureteric anamoly anterior to IVC can be performed in these cases. This case describes a case of retrocaval ureter in a 27year old female with recurrent UTI and flank pain in which open surgical ureteroureteric anastomosis (uretero-ureterostomy) was done with excision of retrocaval part of ureter.

KEYWORDS: Retrocaval ureter, Flank pain, Hydronephrosis (HDN), Uretero-ureterostomy, Urinary tract infection (UTI), Intravenous urogram (IVU).

INTRODUCTION: Rerocaval ureter is a rare congenital abnormality in association with upper urinary tract obstruction and usually has an S-shape or fish hook appearance on IVU that is due to passage of the ureter posterior to IVC. Congenital anamolies that results in the obstruction of ureter are extremely rare, however, retrocaval ureter is the most common anamoly with a renal cause.[1] A more appropriate term would be paravertebral venacava as it is a congenital anamoly of vena cava. But the term retrocaval is now used primarily to describe ureter that simply knuckle behind IVC and reemerge laterally. The majority involve the right ureter, although left sided circumcaval ureter has been reported in association with a duplicated IVC in association with situs invertus.[2] Very few literature on the subject with less number of cases reported in India, we considered it interesting to contribute case history with clinical case of this 27 year old woman.

CASE REPORT: A 27 year old female presented with right flank pain since 5 months, the pain was insidious in onset, progressive in nature and dull aching type. There was also history of burning micturition on intermittent basis. The blood pressure at presentation was 124/80 mm of Hg. There was no abnormality on general examination but on abdominal examination; a slight bulge was noticed in right flank area which was non-tender on palpation, soft in consistency, dull on percussion. Full blood count, urinalysis, blood urea, serum creatinine and viral markers were normal. Abdominal ultrasonography revealed a right sided gross hydronephrosis with paper thin renal cortex. IVU showed delayed function of right kidney and sub-sequently a right sided hydronephrosis and hydro ureter up to third lumbar vertebra. 


\section{CASE REPORT}

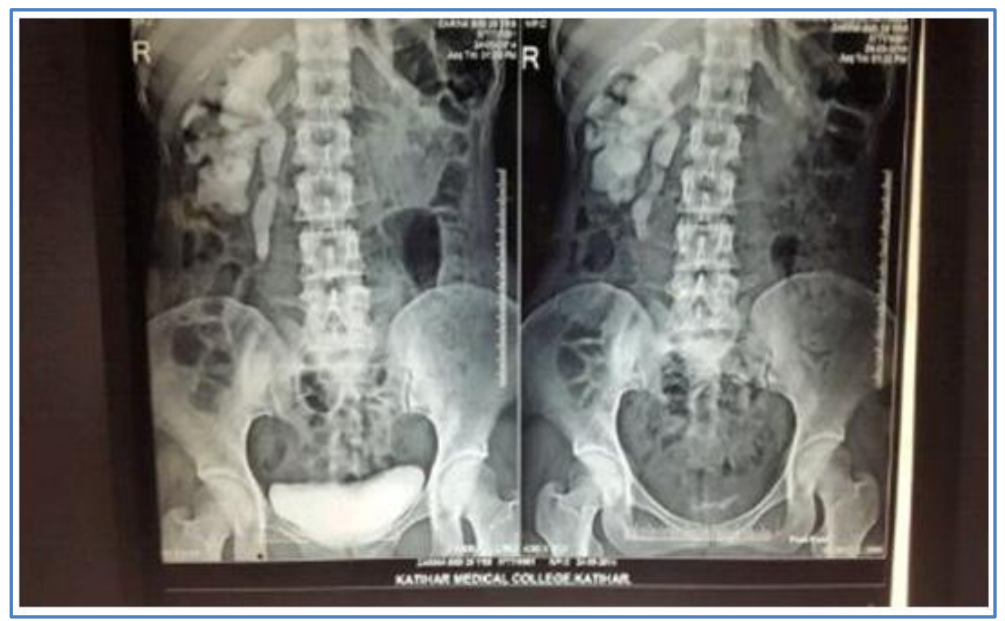

Fig. 1: IVU film showing right sided gross hydrone phrosis and hydroureter

A Computed tomography scan (CT SCAN) of KUB region with plain and contrast film revealed a high grade obstruction of ureter with associated hydronephrosis of right kidney. It excluded any extrinsic lesion as a cause of above findings. A diagnosis of symptomatic right retrocaval ureter was made. The patient had an open surgery through right lumbar abdominal incision. Dilated pelvis and dilated upper ureter was identified and found going behind IVC. The ureter was dissected out, stricture segment (post caval segment) was removed and uretero-ureteric anastomosis was done anteriorly over Double J (D-J) stent. Hemostasis was secured and drain was put in perirenal area.

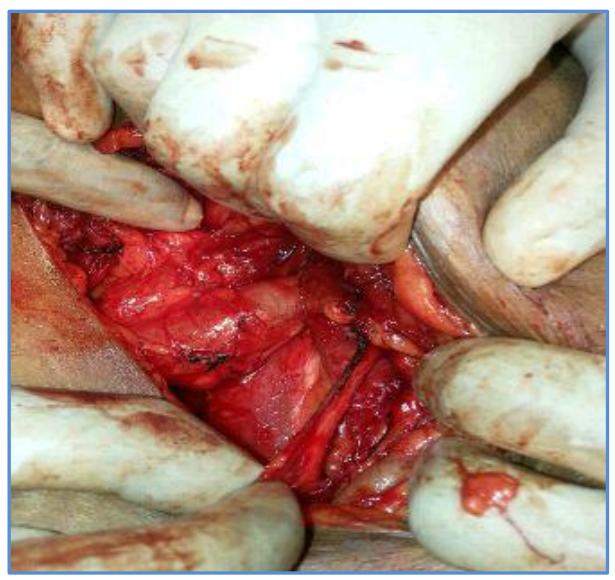

\section{Fig. 2: showing intraoperative picture of dilated upper} ureter and narrowed lower ureter with retrocaval segment

Post-operative event was uneventful. Drain was removed on day four and per urethral foley's catheter was removed on day ten. D-J stent was removed after 6weeks with patient having no fresh complaints till now. 


\section{CASE REPORT}

DISCUSSION: Retrocaval ureter is also known as circumcaval ureter was first reported by Hochstetter in 1893.[3] It is a rare congenital anamoly occurring with incidence of about $1 \mathrm{in}$ 1500people with 3 to 4 times male preponderance on autopsy studies. ${ }^{[4]}$ Retrocaval ureter may be asymptomatic or cause symptoms such as flank pain, UTI, hematuria or calculus formation.[5] Other disorders have been reported to be associated with retrocaval ureter are retroperitoneal fibrosis, carcinoma of ureter and renovascular hypertension.[6][7][8] IVU is advantageous in these cases as it can provide good image resolution and examination can be modified. According to clinical needs, for example, obtaining delayed images or changing patient's position to try out to visualize the entire length of ureter. Although not diagnostic, the appearance of retrocaval ureter on IVU is typical and highly suggestive of diagnosis. ${ }^{[9]}$ Multislice tomography(MSCT), however is performed to confirm the diagnosis and rule out other causes of ureteral deviation. Changing patterns have led to MSCT replacing IVU in assessment of patients with suspected urolithiasis esp. ureteric calculus.[10][11] The radiological features of retrocaval ureter on IVU is divided into two types. In type1, ureter crosses behind IVC at lumber vertebra third with fish hook and S-shaped deformity of ureter. Also known as low loop retrocaval ureter with marked hydronephrosisin $50 \%$ of cases. In type2, Retrocaval segment is at same level of renal pelvis. Also known as high loop with mild hydronephrosis and incidence is less than type1.[12] IVU considered obsolete by some is still valuable in assessment of congenital anamolies like retrocaval ureter. Asymptomatic cases of retrocaval ureter do not need surgery[5] but symptomatic patients generally need surgical intervention which is mainly uretero ureterostomy.[3] Laparoscopic correction of retrocaval ureter is also reported which may be trans peritoneal or extra peritoneal.[13][14][15] In cases of renal dysfunction, nephrectomy is mandatory.[3]

CONCLUSION: Flank pain and UTI are the most common causes of referral in patients with retrocaval ureter. In symptomatic patients, surgical intervention should be performed and renal function improves after the operation. Open surgical exploration is still commonly used technique for retrocaval ureter but it is being replaced by minimally invasive laparoscopic technique with advantage of minimal post-operative pain and shorter convalescence.

\section{REFERENCES:}

1. Rubinstein I, Cavalcanti AG, Freitas MA, Accioly PM. Left retrocaval ureter associated with inferior vena cava duplication, J. Urol., 1999; 162: 1373-74.

2. Watanbe M, Karvamura S, Nakada T, et al: Left preureteral vena cava (retrocavalor circumcaval ureter) associated with partialsitus invertus.J. Urol., 1991; 145: 1047-48.

3. Hochstetter F. Beitrage zur entwick lungsges chichtedes venen-systemsder amnioten: III. Sauger Morph J ahrb.1893: 20: 542.

4. Heslin JE, Mamonas C. Retrocavalureter. Report of four cases and review of literature. J. Urol. $1951 ; 65,212-222$.

5. Cao Avellaneda E, Server Pastor G, Lopez Lopez A, et al. (Non obstructiveretrocavalureter). Actas Urol Esp. 2005; 29: 107-9. Spanish.

6. Arriola PM, el-Droubi H, Dahlen CP. Combined retrocaval ureter and peritoneal fibrosis: report of a case. J. Urol. 1979; 121: 107-8.

7. Fillo J, CervenakovI, MardiakJ, Szeiff S, Kopecny M, Labas P. Retrocavalureter with ureteral carcinoma. Bratis Lek Listy. 2003; 104: 408-10. 
8. TanakaK, AkimotoS, Kozuma Tet al. [Renovascular hypertensionwith a solitary kidney associated with retrocaval ureter: a casereport] Nippon Geka GakkaiZasshi. 1984; 85: 849-54. Japanese.

9. Perimenis P, GyftopoulosK, Athanasopoulos Aet al. Retrocavalureter and associated abnormalities. Int. Urol. Nephrol. 2002; 33(1): 19-22.

10. Chen MY, Zagoria RJ, Saunders HC, Dyer B. Trends in use of unenhanced helical CT for acute urinary colic. AJR AN JRoentgenol. 1999; 173(6); 1447-50.

11. Kambadakone AR, Eisner BH, Catalano OA, Sahani DV. New \& evolving conceptsin imaging and management of urolithiasis: Urologists perspective. Radiographics. 2010; 30(3): 603-23.

12. Bateson EM, Atkinson D. Circumcaval ureter. A new classification. Clin. Radiol. 1969; 20(2): 173-77.

13. Bhandarkar DS, Lalmalani JG, Shivde S. Laparoscopic ureterolysis and reconstruction of a retrocaval ureter. Surg. Endosc. 2003; 17: 1851-52.

14. Miyazato M, Kimura T, Ohyama C, Hatano T, Miyazato T, Ogawa Y. Retroperitoneoscopic Ureteoureterostomy for retrocaval ureter. Hinyokika Kiyo.2002: 48: 25-28.

15. Tobias-Machado M, Lasmac MT, Wroclawski ER. Retroperitoneo scopic surgery with extracorporeal uretero-ureteral anastomosis for treating retrocavalureter. Int. Braz.J. Urol. 2005; 31: 147-150.

\section{AUTHORS: \\ 1. Deepak Pankaj \\ 2. Sanjay Prakash \\ 3. Tushar Singh}

\section{PARTICULARS OF CONTRIBUTORS:}

1. Senior Resident, Department of General Surgery, Katihar Medical College, Katihar.

2. Assistant Professor, Department of General Surgery, Katihar Medical College, Katihar.

FINANCIAL OR OTHER COMPETING INTERESTS: None
3. Junior Resident, Department of General Surgery, Katihar Medical College, Katihar.

\section{NAME ADDRESS EMAIL ID OF THE CORRESPONDING AUTHOR:}

Dr. Deepak Pankaj,

Department of General Surgery,

Katihar Medical College,

Katihar-854105, Bihar.

E-mail: drdeepakpankaj@gmail.com

Date of Submission: 28/01/2015.

Date of Peer Review: 29/01/2015.

Date of Acceptance: 10/02/2015.

Date of Publishing: 19/02/2015. 